\title{
Metabolizable energy levels for semi-heavy laying hens at the second production cycle
}

\author{
Fernando Guilherme Perazzo Costa ${ }^{1}$, Janaine Sena da Costa ${ }^{2}$, Cláudia de Castro Goulart ${ }^{3}, 4$, \\ Denise Fontana Figueiredo-Lima ${ }^{5}$, Raul da Cunha Lima Neto ${ }^{3}$, Bárbara Josefina de Sousa Quirino
}

${ }^{1}$ Departamento de Zootecnia/CCA/UFPB, Areia - PB.

${ }^{2}$ Curso de Graduação em Zootecnia/CCA/UFPB, Areia - PB.

${ }_{3}^{3}$ Programa de Doutorado Integrado em Zootecnia/CCA/UFPB, Areia -PB.

${ }^{4}$ Curso de Zootecnia/CCAB/UVA, Sobral - CE. Bolsista da Funcap.

${ }^{5}$ Bolsista DCR/CCA/UFPB, Areia - PB.

6 Programa de Pós-Graduação em Zootecnia/CCA/UFPB, Areia - PB.

ABSTRACT - This study was carried out to evaluate the energy levels in the diet to obtain better performance rates and quality of eggs from laying hens in the second production cycle. One hundred and eighty Bovans Goldline laying hens with 62 weeks of age were used during four 28-day periods. A completely randomized experimental design was used with four metabolizable energy levels $(2,650,2,725,2,800,2,875$ and 2,950 kcal/kg), each with six replicates of six birds. The energy level of diet did not affect the weight of the egg, yolk, albumen and eggshell, the percentages of yolk, albumen and eggshell, yolk color and egg specific gravity. Feed intake, egg production, egg mass and feed conversion per egg mass and per dozen eggs increased significantly with increasing levels of metabolizable energy. Feed intake decreased linearly as the energy level in the diet increased. The metabolizable energy levels showed a quadratic effect on egg production, egg mass and feed conversion per egg mass and per dozen eggs. The metabolizable energy level of 2,830 kcal/kg was the most appropriate to promote better performance and quality of eggs from laying hens in the second production cycle.

Key Words: egg quality, performance, posture

\section{Níveis de energia metabolizável para poedeiras semipesadas no segundo ciclo de produção}

RESUMO - Este estudo foi realizado com o objetivo de avaliar níveis energéticos na dieta para obtenção de melhores índices de desempenho e qualidade de ovos de poedeiras de segundo ciclo de produção. Utilizaram-se 180 poedeiras com 62 semanas de idade, da linhagem Bovans Goldline, durante quatro períodos de 28 dias. O delineamento utilizado foi o inteiramente casualizado, com quatro níveis de energia metabolizável (2.650, 2.725, 2.800, 2.875 e 2.950 kcal $/ \mathrm{kg}$ de ração), cada um com seis repetições de seis aves. O nível energético da dieta não influenciou os pesos do ovo, da gema, do albúmen e da casca, as porcentagens de gema, albúmen e casca, a coloração da gema e a gravidade específica do ovo. O consumo de ração, a produção de ovos, a massa do ovo e a conversão por massa de ovo e por dúzia de ovo aumentaram significativamente com o aumento dos níveis de energia metabolizável. O consumo de ração reduziu de forma linear conforme aumentou o nível de energia na ração. Os níveis de energia metabolizável tiveram efeito quadrático sobre a produção, a massa do ovo e a conversão por massa e por dúzia de ovo. O nível de energia metabolizável de $2.830 \mathrm{kcal} / \mathrm{kg}$ foi o que promoveu melhor desempenho e qualidade do ovo de poedeiras no segundo ciclo de postura.

Palavras-chave: desempenho, postura, qualidade do ovo

\section{Introduction}

In the laying hens business, several aspects can change the egg productivity and quality and nutrition is one of the most important points. Diets for poultry are formulated according to the amount of nutrients needed for the basic functions of the body and for more efficient production. However, these requirements are not constant and vary with age, gender and environment. Thus, periodic assessments of the levels of nutrients appropriate for each region are required (Costa et al., 2004).

Rosa et al. (1997) have reported that the nutritional requirements of poultry expressed in breeding handbooks, in most cases, are determined by environmental conditions different from those in which the birds will be reared. It is therefore vital that the nutritional determinations are made 
on the environment in which the birds will be reared and will produce.

Semi-heavy laying hens have very different characteristics that determine the specific nutritional requirements for each phase. However, due to these characteristics, many times the difficulties in achieving the desired body weight standards or feed intake require interference in the nutrient density of feeds or in specific formulations. It is therefore important to respect the genetic characteristics of breeds and the information contained in the proposed management handbooks (Stringhini et al., 2005).

As in all species, energy is the main nutritional component that influences the bird performance (NRC, 1994) and its requirements change according to body weight, production phase, egg size, breed and room temperature (Coon, 2002). According to Morris (2004), when the energy density of the diet is low, the bird increases the consumption of diet to the point where this intake meets their needs for energy.

According to Harms et al. (2000), the energy use efficiency by laying hens depends on certain genetic characteristics of the bird. Faria \& Santos (2005), in turn, reported that the energy requirement of laying hens is linearly related to body weight in the range from 1.2 to $2.5 \mathrm{~kg}$, considering the metabolic weight and egg mass daily production.

According Albino \& Barreto (2003), the birds in production tend to consume more to meet its energy needs; therefore, the increase in the energy levels of diet decreases the amount of feed intake. The energy content of the diet for laying hens can range from 2,800 to $2,900 \mathrm{kcal} / \mathrm{kg}$, depending of the production stage in which the bird is found. It is important to adjust the density of all nutrients to energy levels (actual amount of feed intake). One can work with decreasing dietary energy levels along the posture cycle, but only after the egg mass peak and within the levels indicated.

This work was carried out to determine the metabolizable energy requirements (ME) for better performance and quality of eggs from commercial semi-heavy laying hens in the second production cycle.

\section{Material and Methods}

The experiment was conducted in the Poultry Sector of the Department of Animal Science - Agricultural Sciences Center, Federal University of Paraiba, Campus II in the municipality of Areia.
One hundred and eighty Bovans Goldline laying hens with 62 weeks of age and initial weight of $1,900 \pm 150 \mathrm{~g}$ were used. The birds were allotted to a completely randomized design with five metabolizable energy levels in the diet and six replications of six birds each. The ground corn-soybean meal based diets were formulated to provide metabolizable energy levels of 2,650, 2,725, 2,800, 2,875 and 2,950 kcal/kg (Table 1).

The laying hens were housed in wire cages $(24 \mathrm{~cm} \times$ $37 \mathrm{~cm} \times 41 \mathrm{~cm}$ ). The light program adopted was natural light and water was provided ad libitum. The diets were fed only once during the day, at 7:00 pm, in amounts of $115 \mathrm{~g} / \mathrm{bird} /$ day.

The experiment lasted 112 days and was composed of four 28-day periods. The birds were weighed at the beginning of the experiment for weight standardization per experimental plot and then submitted to a pre-trial period of 10 days.

The variables analyzed in each period were: feed intake (g/bird/day), egg production (\%), egg weight (g) and egg mass (g/bird/day), feed conversion per egg mass $(\mathrm{kg} / \mathrm{kg})$ and per dozen eggs $(\mathrm{kg} / \mathrm{dz})$, weight $(\mathrm{g})$ and percentage (\%) of yolk, albumen and shell and egg specific gravity.

At the end of each trial period, the diets orts were collected from each plot for the feed intake calculation. The collection of eggs was carried out twice a day (at 10:00 am and 4:00 pm) and data were recorded as laying frequency, recording the number of intact and broken eggs and the mortality rate. The egg production in percentage was calculated by dividing the number of eggs per plot by the number of birds. The eggs of the last four days of each trial period were individually weighed to obtaining the average egg weight. The calculations of the egg mass were performed by the product of the egg production and the average egg weight per plot and the feed conversion per egg mass were calculated by the ratio between the feed consumption and the egg mass produced. The feed conversion per dozen eggs was calculated by the relationship between the feed consumption and production and the result was multiplied by 12 . At the end of each trial period, four eggs per plot were separated for determining the weight and percentage of yolk, albumen and eggshell. After manual separation of these components, the eggshells were placed in oven at $105^{\circ} \mathrm{C}$ for 2 hours (Silva $\&$ Santos. 2000). The percentage was obtained by dividing the weight of these variables by the average weight of eggs which was multiplied by 100 .

Egg specific gravity was determined by the saline flotation method according to methodology described by 
Table 1 - Composition the experimental diets ${ }^{1}$

\begin{tabular}{|c|c|c|c|c|c|}
\hline Ingredient & \multicolumn{5}{|c|}{ Metabolizable energy levels (kcal/kg) } \\
\hline Ground corn & 62.766 & 62.934 & 64.685 & 68.125 & 66.961 \\
\hline Corn gluten meal & 0.904 & 0.943 & 0.500 & 0.286 & 0.421 \\
\hline Soybean oil & 0.200 & 1.000 & 1.297 & 1.000 & 2.238 \\
\hline DL-Methionine & 0.153 & 0.153 & 0.154 & 0.152 & 0.152 \\
\hline Dicalcium phosphate & 1.283 & 1.283 & 1.276 & 1.267 & 1.270 \\
\hline Salt & 0.423 & 0.423 & 0.422 & 0.420 & 0.421 \\
\hline Inert (washed sand) & 6.093 & 5.170 & 3.309 & 0.752 & 0.500 \\
\hline Choline chloride (70\%) & 0.070 & 0.070 & 0.070 & 0.070 & 0.070 \\
\hline Mineral $\operatorname{mix}^{2}$ & 0.050 & 0.050 & 0.050 & 0.050 & 0.050 \\
\hline Vitamin $\operatorname{mix}^{3}$ & 0.025 & 0.025 & 0.025 & 0.025 & 0.025 \\
\hline Metabolizable energy (kcal/kg) & 2,650 & 2,725 & 2,800 & 2,875 & 2,950 \\
\hline Protein (\%) & 15.000 & 15.000 & 15.000 & 15.000 & 15.000 \\
\hline Calcium (\%) & 3.650 & 3.650 & 3.650 & 3.650 & 3.650 \\
\hline Available phosphorus (\%) & 0.326 & 0.326 & 0.326 & 0.326 & 0.326 \\
\hline Sodium $(\%)$ & 0.200 & 0.200 & 0.200 & 0.200 & 0.200 \\
\hline Total lysine (\%) & 0.731 & 0.734 & 0.732 & 0.733 & 0.733 \\
\hline Digestible lysine (\%) & 0.652 & 0.655 & 0.652 & 0.652 & 0.652 \\
\hline Total Met + Cist (\%) & 0.654 & 0.654 & 0.654 & 0.655 & 0.654 \\
\hline Digestible Met + Cist (\%) & 0.593 & 0.593 & 0.593 & 0.593 & 0.593 \\
\hline Total methionine (\%) & 0.398 & 0.398 & 0.398 & 0.396 & 0.396 \\
\hline Digestible methionine (\%) & 0.376 & 0.376 & 0.376 & 0.374 & 0.374 \\
\hline
\end{tabular}

Hamiltom (1982). At the end of each trial period, representative samples of 2 eggs per plot were selected and then the eggs were immersed in different saline solutions with volume adjustment for 25 liters of water in density from 1,060 to 1,100 with an interval of 0.0025 . The eggs were placed in buckets with the solutions from the lowest to the highest density and removed when fluctuate to record the respective values of the densities corresponding to the solutions of the containers. Before each evaluation, the densities were checked with an oil densimeter.

The results were submitted to statistical analysis using the SAEG program (UFV, 1999) for polynomial regression analysis using the linear and quadratic effects for determining the metabolizable energy requirements.

\section{Results and Discussion}

The mortality rate during the experimental period was $3.33 \%$ and was not affected by the energy levels in the diet
(Table 2). Feed intake was influenced linearly decreasing $(\mathrm{P}<0.01)$ by the energy levels and for each increase of $75 \mathrm{kcal}$, the estimated reduction in consumption was $1.29 \mathrm{~g} /$ bird/day according to equation $\hat{\mathrm{Y}}=159.98-0.0172 \mathrm{x}$ $\left(r^{2}=0.75\right)$. This reduction in consumption can be partially explained by the bird ability to regulate its feed consumption according to the dietary energy content (Morris, 2004).

According to Bertechini (1997), poultry and pigs have ability to consume certain amounts of feed in order to meet primarily their energy requirements. Thus, any change in the energy level of diet can change the consumption of energy and all nutrients. In work conducted by Ost \& Peixoto (2000) with the metabolizable energy levels of $2,650,2,750,2,850$ and 2,950 kcal/kg, the results showed feed intake decreased with increasing energy concentrations in diets. On the other hand, Colvara et al. (2002) using 2,700, 2,800, 2,900 and 3,000 of ME kcal/kg for laying hens in the second cycle in the summer found no significant variation in feed intake between the metabolizable energy levels. 
Table 2 - Performance and productivity of laying hens according to dietary metabolizable energy levels

\begin{tabular}{|c|c|c|c|c|c|c|c|c|c|}
\hline \multirow[t]{2}{*}{ Characteristic } & \multicolumn{5}{|c|}{$\begin{array}{c}\text { Metabolizable energy level } \\
(\mathrm{kcal} / \mathrm{kg})\end{array}$} & \multirow[t]{2}{*}{ Mean } & \multirow[t]{2}{*}{ Requirement } & \multirow[t]{2}{*}{ Effect } & \multirow[t]{2}{*}{ CV (\%) } \\
\hline & 2,650 & 2,725 & 2,800 & 2,875 & 2,950 & & & & \\
\hline Egg production (\%) & 66.0 & 74.3 & 74.5 & 69.9 & 67.5 & 70.4 & 2,798 & $\mathrm{Q}^{*}$ & 6.63 \\
\hline Egg weight (g) & 67.0 & 66.0 & 66.5 & 66.8 & 65.5 & 66.4 & - & ns & 2.81 \\
\hline Egg mass (g/bird/day) & 44.2 & 49.0 & 49.4 & 46.7 & 44.1 & 46.7 & 2,794 & $\mathrm{Q}^{*}$ & 7.68 \\
\hline
\end{tabular}

CV - Coefficient of variation; ns - Not significant; L - Linear effect; Q - Quadratic effect

* $\mathrm{P}<0.05 ; * * \mathrm{P}<0.01$.

A quadratic effect of the metabolizable energy levels on the egg production, egg mass, feed conversion per egg mass and per dozen eggs was observed in this study $(\mathrm{P}<0.05)$, while the egg weight was not influenced by the energy levels in the diet $(\mathrm{P}>0.05)$. A possible explanation for this response, namely to increase the egg mass production and to improve feed conversion up to a certain energy level with declining response after this point was likely due the reduction in the efficiency energy use of the feed with increasing in energy density of the diet (Peguri \& Coon. 1991). Sakomura et al. (1993) emphasized that the voluntary consumption of energy often exceeds the maintenance and production demand causing an increase in weight gain, firstly as fat with consequent increasing of the maintenance demand and loss in energy use efficiency undermining production. Another factor that may have contributed to the quadratic response is the relationship between energy consumption and the consumption of other nutrients mainly crude protein and essential amino acids. The increase of 2.8 or $5.6 \%$ in the supply of metabolizable energy (from 2,650 to 2,725 and 2,800 kcal/kg. respectively) almost did not change the consumption of diet and the consumption of protein and amino acids lysine and methionine. However, an increase of 8.4 and $11.2 \%$ in the metabolizable energy of the diet (from 2,650 to 2,875 and 2,950 kcal/kg) reduced the consumption of diet, protein and amino acids at 1.6 and $5.2 \%$ respectively and may have limited the egg and egg mass production and worsened the feed conversion.

The equations $\hat{\mathrm{Y}}=2497.14+1.8381 \mathrm{x}-0.000328507 \mathrm{x}^{2}$ $\left(r^{2}=0.82\right)$ and $\hat{\mathrm{Y}}=-1652.4+1.21777 \mathrm{x}-0.0002179 \mathrm{x}^{2}$ $\left(r^{2}=0.92\right)$ were used to estimate the best egg production and the greatest egg mass with levels of 2,798 and 2,794 kcal of ME/ kg of diet, respectively. Similar results were observed by Xavier \& Peixoto (1997) who obtained quadratic responses in the egg production when laying hens were fed diets containing 2,650 to 2,950 kcal of ME/kg.
According to Leeson \& Summers (1997), the egg production in laying hens increases rapidly when the metabolizable energy levels increase in the diet. Leeson et al. (2001), however reported that when the nutritional balance was achieved with low-density diets $(2,465 \mathrm{kcal} / \mathrm{kg}$ and $15 \% \mathrm{CP}$ ), the current laying hens seem to have improved their performance. On the other hand, some studies have shown that the egg production was not affected by the energy content of the diet (Harms et al., 2000; Ost \& Peixoto, 2000; Leeson et al., 2001). In a study conducted by Costa et al. (2004), no significant results were obtained for the egg production when diets with energy levels from 2,645 to 2,971 ME kcal/kg of ration were supplied.

According to Albino \& Barreto (2003), the supply of energy in excess can cause super ovulation increasing the production of eggs with two yolks. Moreover, other ovules will be reabsorbed in the abdominal cavity, so that the bird can remain without laying eggs for several days. The egg production increases when protein and fat are deposited and there is a association between optimum production and start of obesity.

Similar results for egg mass were obtained by Xavier \& Peixoto (1997) who observed quadratic responses in the egg production when laying hens were fed diets containing 2,650 to 2,950 kcal of ME/kg. Ost \& Peixoto (2000) obtained decreasing quadratic response in the egg mass when the hens were fed diets containing 2,650 to 2,950 kcal ME/kg and observed largest egg mass at the initial level of 2,650 kcal EM/kg, unlike results were reported by Costa et al. (2004) who have not found significant responses for egg mass.

The best feed conversion per egg mass (2.343) was estimated with the level of 2,818 kcal ME/kg of ration ( $\hat{\mathrm{Y}}=60.6764-0.0414014 \mathrm{x}+0.000007346 \mathrm{x}^{2} ; \mathrm{r}^{2}=0.81$ ), while the best feed conversion per dozen eggs (1874) was estimated with the level of 2,830 kcal ME/kg of ration ( $\hat{Y}=42.6390$ $\left.0.0287978 \mathrm{x}+0.00000508594 \mathrm{x}^{2} \cdot \mathrm{r}^{2}=0.71\right)$. The results 
observed in this study are consistent with those reported by Xavier \& Peixoto (1997) who obtained quadratic response in the feed conversion per egg mass when laying hens were fed diets containing 26,50 to 2,950 kcal $\mathrm{EM} / \mathrm{kg}$, the best feed conversion occurred for intermediate energy levels in the diet and the worse with extreme energy levels (Table 3).

It is known that the energy use efficiency in feed for egg production and weight gain may decrease as the energy density of the diet increases or alternatively the amount of energy required per weight gain unit can increase according with the energy level per kilogram of diet (Peguri $\&$ Coon. 1991) which may worsen the feed conversion (Ost \& Peixoto, 2000).

There was no effect $(\mathrm{P}>0.05)$ of the metabolizable energy levels of diet on the weights and percentages of albumen, yolk and eggshell or on the egg specific gravity. The average value obtained for the specific gravity (1.081) was similar to that reported by Freitas et al (2004) who compared methods for determining the egg specific gravity and found the average value of 1.086 and average egg weight of $58.5 \mathrm{~g}$. The average weight of egg obtained in this experiment was $66.5 \mathrm{~g}$.

Egg specific gravity (SG) was an estimate of the amount of eggshell deposited and is related to the eggshell percentage. According to Hamilton (1982), egg specific gravity increases according to the thickness of the eggshell. Peebles \& McDaniel (2004) considered in their work the egg specific gravity value of 1.080 as the threshold between the low and high quality of egg shells. In this work, only the level of 2,650 ME $\mathrm{kcal} / \mathrm{kg}$ of ration resulted in egg specific gravity less than this limit.

Table 3 - Egg characteristics of laying hens according to dietary metabolizable energy levels

\begin{tabular}{|c|c|c|c|c|c|c|c|}
\hline \multirow[t]{2}{*}{ Characteristic } & \multicolumn{5}{|c|}{$\begin{array}{c}\text { Metabolizable energy level } \\
(\mathrm{kcal} / \mathrm{kg})\end{array}$} & \multirow[t]{2}{*}{ Mean } & \multirow[t]{2}{*}{ CV (\%) } \\
\hline & 2,650 & 2,725 & 2,800 & 2,875 & 2,950 & & \\
\hline Albumen (g) & 43.4 & 42.1 & 42.4 & 42.4 & 42.6 & 42.6 & 5.30 \\
\hline Yolk (g) & 17.5 & 17.6 & 17.4 & 18.1 & 17.4 & 17.6 & 3.60 \\
\hline Eggshell (g) & 6.3 & 6.3 & 6.3 & 6.3 & 6.0 & 6.2 & 4.93 \\
\hline Albumen (\%) & 64.8 & 63.9 & 63.7 & 63.6 & 65.1 & 64.2 & 3.74 \\
\hline Yolk (\%) & 26.1 & 26.7 & 26.2 & 27.1 & 26.3 & 26.5 & 4.36 \\
\hline Eggshell (\%) & 9.4 & 9.6 & 9.4 & 9.4 & 9.2 & 9.4 & 4.15 \\
\hline Egg specific gravity & 1.080 & 1.080 & 1.081 & 1.081 & 1.080 & 1.080 & 3.01 \\
\hline
\end{tabular}

CV - Coefficient of variation; ns - Not significant

\section{Conclusions}

The metabolizable energy level of $2,830 \mathrm{kcal} / \mathrm{kg}$ diet for commercial laying hens in the second production cycle is recommended to meet the nutritional requirements of poultry.

\section{Literature Cited}

ALBINO, L.F.T.; BARRETO, S.L.T. Criação de codornas para produção de carne. Viçosa, MG: Aprenda Fácil. 2003, 289p.

BERTECHINI, A.G. Nutrição de monogástricos. Lavras: UFLA/ FAEPE, 1997. 274p.

COLVARA, I.G.; MAIER, J.C.; RUTZ, F. et al. Níveis de energia metabolizável em rações para poedeiras semipesadas durante o segundo ciclo de produção no verão Revista Brasileira de Agrociência, v.8, n.1, p.47-49, 2002.

COON, N.C. Feeding egg-type replacement pullets. In: BELL, D.D. (Ed.) Commercial chicken meat and egg production. Massachusetts: Kluwer Academic, 2002. p.287-393.

COSTA, F.G.P.; SOUZA, H.C.; GOMES, C.A.V. et al. Níveis de proteína bruta e energia metabolizável na produção e qualidade dos ovos de poedeiras da linhagem Lohmann Brown. Ciência Agrotécnica, v.28, n.6, p.1421-1427, 2004.
FARIA, D.E.; SANTOS, A.L. Exigências nutricionais de galinhas poedeiras. In: SIMPÓSIO INTERNACIONAL SOBRE EXIGÊNCIAS NUTRICIONAIS DE AVES E SUÍNOS, 2005, Viçosa, MG. Anais... Viçosa, MG: 2005. p.229-315.

FREITAS, E.R.; SAKOMURA, N.K.; GONZALES, M.M. et al. Comparação de métodos de determinação da gravidade específica de ovos de poedeiras comerciais. Pesquisa Agropecuária Brasileira, v.39, n.5, p.509-512, 2004.

HAMILTOM, R.M.G. Methods and factors that affect the measurement off egg shell quality. Poultry Science, v.61, p.2002-2039, 1982.

HARMS, R.H.; RUSSEL, G.B.; SLOAN, D.R. Performance of four strains of commercial layers with major changes in dietary energy. Journal of Applied Poultry Research, v.9, p.535541, 2000.

LEESON, S.; SUMMERS, J.D.; CASTON, L.J. Response of layers to low nutrient density diets. Journal of Applied Poultry Research, v.10, p.46-52, 2001.

LEESON, S.; SUMMERS, J.D. Commercial poultry nutrition. 2.ed. Guelph: University Book, 1997. 350p.

MORRIS. T.M. Nutrition of chicks and layers. World's Poultry Science Association, v.60, p.5-12, 2004.

NATIONAL RESEARCH COUNCIL - NRC. Nutrient requirements of poultry. 9.ed. Washington, D.C.: National Academy Press, 1994. 155p.

OST, R.P.; PEIXOTO, R.R. Níveis de energia metabolizável em rações para poedeiras de ovos marrons nas condições de inverno e verão 
na região de Pelotas-RS. Revista Brasileira de Zootecnia, n.6, v.29, p.283-2291, 2000.

PEEBLES, E.D.; McDANIEL, C.D. A practical manual for understanding the shell structure of broiler hatching eggs and measurements of their quality. Mississipi: State University, 2004. (Bulletin, 1139).

PEGURI, A.; COON, C. Effect of temperature and dietary energy on layer performance. Poultry Science, v.70, p.126-138, 1991.

ROSA, A.P.; ZANELLA, I.; THEIR, J. et al. Influência de diferentes níveis de proteína bruta e energia metabolizável no desempenho de poedeiras Rhode Island Red na fase de recria. Revista Brasileira de Zootecnia, v.26, n.1, p.159-163, 1997.

ROSTAGNO, H.S. Tabelas brasileiras para aves e suínos: composição de alimentos e exigências nutricionais. Viçosa, MG: UFV. 2000. 141p.
SAKOMURA, N.K.; ROSTAGNO, H.S.; COUTO, H.P. et al. Alimentação de poedeiras semipesadas. usando equações de predição das exigências energéticas. Revista Brasileira de Zootecnia, v.22, n.6, p.1019-1032, 1993.

SILVA, J.H.V.; SANTOS, V.J. Efeito do carbonato de cálcio na qualidade da casca de ovos durante a muda forçada. Revista Brasileira de Zootecnia, v.29, n.5, p.1440-1445, 2000.

STRINGHINI, J.H.; JARDIM FILHO, R.M.; PEDROSO, A.A. et al. Nutrição no período de pré-postura. Pico e pós-pico de poedeiras comerciais. In: CONFERENCIA APINCO DE CIÊNCIA E TECNOLOGIA AVÍCOLA, 2005, Santos. Anais... Santos: Fundação Avícola de Ciência e Tecnologia Avícolas, 2005. p.171-189.

XAVIER. E.G.; PEIXOTO, R.R. Nível de energia metabolizável em rações para poedeiras nas condições de temperatura e umidade relativa do inverno do extremo sul do Brasil. Revista Brasileira de Zootecnia, v.26, n.2, p.364-374, 1997. 